\section{The Nutrition Society}

THE science of nutrition expanded so much of recent years that it was no longer adequately covered by existing societies. In July 1941, therefore, a proposal to form a nutrition society was put forward, under the auspices of the heads of various well. known institutes engaged in research on nutrition in Britain, which would follow on the lines of the Physiological and Biochemical Societies, although there was no question of publishing a journal at that time. At the first meeting in the same month, it was felt that the main object of the new Society should be to form a common meeting place for workers in the various fields of nutrition, namely, physiological, biochemical, agricultural, medical, sociological, economic and public health, and that it would be useful during the War to have a separate Scottish Group. The Society had not long been founded when it became apparent that the value of its proceedings would be enhanced by their reaching an audience wider than that which actually participated in its meetings. The Royal College of Physicians, impressed with the advantage which the medical profession might reap from gaining immediate access to the records of the meetings of the Society, made an offer which enabled the financial and other difficulties standing in the way of publication during war-time to be overcome. Accounts of the first meoting and of English and Scottish Group meetings up to May 30, 1942, are now published (Proc. Nutrition Soc., 1, Nos. 1 and 2, 1-112; 1944) and include "Evaluation of Nutritional States ; Food Production, Distribution and Supplies in Relation to Human Needs", and "Problems of Collective Feeding in War Time". The second double number will contain reports of meetings on dehydration, food supplies, trace elements and diet in pregnancy and lactation.

\section{British Medicine and the Göttingen Medical School}

IN a recent paper (Bull. Hist. Med., 14, 449 ; 1943) Prof. Max Neuburger remarks that during the eighteenth century inadequate facilities for teaching and research prevented most of the medical schools in Germany from furthering either medical training or scientific research. On the other hand, the medical school at Vienna and the Medical Faculty at Göttingen were remarkable exceptions, and owed their celebrity to two famous pupils of Boerhaave, namely, Gerhard van Swieten at Vienna and Albrecht v. Haller at Göttingen. George II, who founded the University of Göttingen in 1734, invited Haller to fill the vacant chair of medicine, which included anatomy, surgery and botany. Haller had previously spent some time in London, where he made the acquaintance of several English physicians and surgeons such as Sir Hans Sloane, John Pringle and William Cheselden, and frequently quoted British writers, notably Stephen Hales, John Mayow and Thomas Willis, in his own works. During the seventeen years when he resided at Göttingen, he exercised a great influence on the University, being responsible for the erection of an anatomical theatre, a botanical garden and a lying-in institution. He also founded a scientific society of which he was the first and permanent president, and a scientific journal to which he made more than a thousand contributions. Between 1739 and 1744 he completed the six-volume edition of Boerharve's "Institutiones", for which he was elected a foreign member of the Royal Society. $\mathrm{He}$ was also author of numerous other works on anatomy, physiology, medicine, surgery and botany. In 1739 he was appointed physician in ordinary to George II, who conferred a knighthood upon him and made him one of his consultant physicians. Owing to reasons of health, he left Göttingen for Berne in 1753. Many of Haller's successors at Gött. ingen, as Prof. Neuburger points out, had studied in London. Among them may be mentioned Roederer, Sömmering, Thomas Young and Blumenbach.

\section{Quekett Microscopical Club}

For some eighty years, the Quekett Microscopical Club has taken a leading part in the development of microscopy, and many leading research workers have been included on its membership roll and have recorded the results of their work in its journal. Thanks to the courtesy of the Royal Society, the Club, which at present has a membership of nearly three hundred and fifty, is now meeting at Burlington House, Piccadilly, where the Club's library and slide cabinet are again available, after having been removed to safety in the country during the last four years. Meetings are held as originally, on the second and fourth Tuesday in each month, the earlier being an ordinary (lecture) meeting, whereas the latter is devoted to the exhibition of specimens, apparatus and general discussion. On Saturday afternoons, collecting excursions are conducted and visits to places of interest to microscopists are arranged. The affairs of the Club are managed by two secretaries: Mr. E. P. Herlihy, 76 Brook Green, London, W.6, dealing with business matters, and Dr. James David. son, 41 Brampton Grove, London, N.W.4, with scientific matters and papers.

\section{Chagas's Disease in Brazil}

IN a recent paper (Bol. Of. San. Panamericana, 22, 773 ; 1943), C. Chagas, jun., states that during the thirty-three years since Chagas's disease was discovered in a small area in the State of Minas Gerais, Brazil, the disease has been found to have spread throughout North and South Amorica. As regards the parasitology, it is now universally accepted that Schizotrypanum is the cause of the disease. Studies are now being made to obtain more complete data regarding insect vectors, prevalence of the disease and animal carriers of the virus. Among domestic animals, cats and dogs take the first place as carriers.

\section{Work at the Madrid Observatory}

Butuerin 9 from the Madrid Observatory deals first of all with the photographic and visual observations of Novi Lacertæ 1936, made at the Observatory. The photographs were obtained by means of a camera of short focus used in conjunction with the Grubb photographic equatorial, which has an aperture of $16 \mathrm{~cm}$. and focal length $80 \mathrm{~cm}$. The method employed for determining the magnitude of the nova was by measuring the diameters of the focal images, and applying the formulæ of Charlier and Parkhurst, adopting the mean from both formulo. Nine comparison stars of various spectral types were used and the results are shown in Table 2 , the observations extending over the period June 21-July 17, 1936. In addition to the photographic observations, about 500 visual observations were made between June 18 and July 20, the results of which are given in Table 3, and from these the colour-index was deduced. This varied according to the spectral type of comparison star; for Class $F 0$ it was $0 \cdot 30$ and for Class $B 8$ it 